\title{
Refugees and Internally Displaced Persons in the Former Yugoslavia in the Light of Dayton and Paris Agreements
}

\author{
Vladimir Grecic
}

\begin{abstract}
This paper provides an overview and assessment of implementation of the Dayton Peace Agreements, particularly the part referring to refugees and internally displaced persons. The establishment of peace in Bosnia and Herzegovina in accordance with the Dayton Agreement and the subsequent normalization of life in the former $Y u$ goslavia should create prerequisites for unobstructed return of over 2 million individuals to their homes. Therefore, we will review the number of refugees from the territory of the former Yugoslavia, places of their present residence, their problems and possibilities for their return to areas where they used to live.
\end{abstract}

\section{Précis}

Cet article fournit un aperçu et une évaluation de la mise en place des accords de paix de Dayton, et particulièrement de la partie référant aux réfugiés et aux personnes déplacées à l'intérieur du pays. L'établissement de la paix en Bosnie et en Herzégovine en conformité avec l'accord de Dayton, et la normalisation de la vie en ex-Yougoslavie y faisant suite, deoraient créer les conditions préalables pour le retour sans encombre de plus de 2 millions d'individus vers leurs foyers. Conséquemment, nous allons passer en reoue le nombre de réfugiés éparpillés sur le territoire de l'ex-Yougoslavie, le lieu de leur résidence actuelle, les conditions favorables et défavorables d leur retour vers les zones où ils vivaient auparavant.

Prof. Vladimir Grecic, Ph.D. in Economics, is Senior Research Fellow and Deputy Director of the Institute of International Politics and Economics in Belgrade, FRY. He teaches Economics of Labour at the School of Economics, University of Belgrade, FRY.

The views expressed in this article are those of the author and should not be interpreted as those of the staff of Refuge.

\section{Introduction}

The territory of the former Yugoslavia, particularly Bosnia and Herzegovina, is one of the most complex regions in Europe, from which vast numbers of population in recent years had to flee and seek refuge somewhere else. UNHCR assesses that in early 1996, over 2.6 million persons from BosniaHerzegovina lived away from their homes. Internally displaced persons (IDPs) numbered $1,282,257$, in addition to 661,473 in other states of the former Yugoslavia and 697,198 outside former Yugoslavia. It is worth noting that people also fled from other newly founded states in ex-Yugoslav territory, above all from the Republic of Croatia. Bosnia-Herzegovina, as the refugees' territory of origin, occupied in mid-1990s the 4th place in the world (after Palestine, Afghanistan and Rwanda) in terms of the number of refugees and displaced persons, and complexity of ensuing problems. ${ }^{1}$

However, in this paper we will not deal separately with causes of contemporary refugee problem in ex-Yugoslavia, at least for two reasons. Firstly, the roots of the Yugoslav crisis, which lasted for about six years, were the topic of many books, studies and articles. ${ }^{2}$ They mainly explain the origin of ethric conflicts, civil war and forceful population movement from their hearths. The civil war, no doubt, was caused by internal, as well as external factors. ${ }^{3}$ Secondly, from such a short historical distance and while the actors of the Yugoslav drama are still in power, the share of foreign factors cannot be strictly determined yet. It will be possible from a longer historic distance, when stenographic notes become available to researchers. Given the nature of existing data on the causes of the crises, we will review the number of refugees from the territory of the former Yugoslavia, their present residence, their problems, and possibilities for their return to areas where they used to live.

The Dayton Peace Agreement was signed in Paris, on 14 December 1995. Annex 7 of that agreement envisages that UNHCR should promote voluntary return for all those who wish to return to the region they fled from, but also for those refugees and displaced persons from ex-Yugoslavia who would like to find another permanent solution somewhere else, in some other community, in the territory of the former Yugoslavia or outside it. Permanent solutions will therefore develop on the basis of refugees' intentions and political reality in the country of displacement, country of return, or country of exile.

\section{Dimensions of the Problem}

As already mentioned, over 2.6 million inhabitants of Bosnia-Herzegovina were externally and internally displaced by the civil war. The majority were internally displaced (see Table 1).

A major exodus from the Republic of Croatia also took place in August 1995. With the aggression on newlyfounded Republic of Serb Krajina (operations "Lightning" and "Storm"), the Republic of Croatia expelled almost all Serbs from Krajina. Out of 200,000 Serbs who lived there before the Croatian aggression, only an estimated 5,000 remained. ${ }^{4}$

The reasons for escape are numerous and not mutually exclusive. Families surveyed in 1993 in the Federal Republic of Yugoslavia (FRY) mentioned most frequently the following main reasons for leaving their homes:

- threat of war,

- fear and insecurity,

- threats of enemies or hostile population in the neighbourhood, 
Table 1: Bosnia and Herzegovina: Refugees/Displaced Persons, 1996

\begin{tabular}{lcr}
\hline Refugees & Total & 1996 Movement \\
\hline Europe and Other Countries & $697,198^{*}$ & $200,000^{*}$ \\
Neighbouring Countries (FY) & & \\
Croatia & 185,669 & $80,000^{*}$ \\
FRY & $450,000^{*}$ & $80,000^{*}$ \\
Slovenia & 18,804 & $8,000^{*}$ \\
FYROM & $7,000^{*}$ & $4,000^{*}$ \\
(FY Subtotal) & $661,473^{*}$ & $172,000^{*}$ \\
Internally Displaced Persons & $1,282,257^{*}$ & $500,000^{*}$ \\
Total & $2,640,928$ & 872,000 \\
\hline
\end{tabular}

* Estimates

Source: UNHCR, March 1996.

- expulsion by the enemy, destruction of property, physical and psychological harassment, and

- death or wounding of family member. $^{5}$

The dimension of problems facing the refugees is significant. Refugees' living conditions were poor in almost all the states of the former Yugoslavia. In FRY, 73.3 percent of refugees have stayed with families (relatives, friends, unknown humane people), 21.5 percent in rented quarters and 5.2 percent in collective shelters (schools, kindergartens, hospitals, military barracks). Due to the war, economic and political problems and effects of UN Sanctions against FRY, the living standard is low. Thus, refugees shared the fate of population in FRY.

\section{Permanent Solution of Refugee and Internally Displaced Persons Problem in the Light of the Peace Agreement}

In accordance with the Dayton Peace Agreement, the UNHCR plan envisages repatriation of over two million refugees and internally displaced persons, currently living in various parts of the former Yugoslavia or abroad, particularly in Western Europe.

The repatriation plan has three stages. The first one anticipates the return of nearly 1.3 million displaced persons currently in Bosnia-Herzegovina, encompassing:

- 250,000 in the Banjaluka region,

- 45,454 in the Bihac region,

- 265,000 in eastern Bosnia,

- 93,379 in Sarajevo,

- 100,622 in southern Bosnia (Herzegovina),

- 288,890 in the Tuzla region, and

- 241,912 in the Zenica region.

In the second stage, UNHCR should organize the return of some 661,473 refugees who fled to FR Yugoslavia, Croatia, Slovenia and Macedonia.

According to UNHCR data, there are 566,000 refugees in the FRY $(28,000$ in Montenegro and 538,000 in Serbia). Of these refugees, some 253,000 are from Bosnia and Herzegovina (of whom 50,000 originate from the territory of what is now Republika Srpska and 203,000 from the Federation) and 298,000 are from Croatia and 15,000 are from other republics of the former Yugoslavia.
According to the latest UNHCR data, there are 160,000 refugees in the Republic of Croatia: 85,000 from the Bosnian Federation (85\% Croats, $15 \%$ of other nationalities) and 75,000 from Republika Srpska (85\% Croats, $15 \%$ of other nationalities), 10,420 in Slovenia (mainly Muslims) and 5,000 in Macedonia (mainly Muslims).

In the third stage, according to UNHCR data, about 700,000 refugees from ex-Yugoslavia should return from Western European countries.

The entire operation, according to UNHCR estimates, would cost some U.S. $\$ 500$ million. Repatriation of refugees is planned to be carried out with the participation of International Organization for Migrations (IOM), the Red Cross and Organization for Security and Cooperation in Europe (OSCE).

IFOR has managed to restore peace in Bosnia-Herzegovina and made it possible for humanitarian organizations to continue their care for internally displaced persons and refugees. IFOR has also been in charge of providing conditions for general elections in Bosnia-Herzegovina.

Together with the Bosnian-Croat Federation and Republika Srpska, UNHCR worked out the Program of Support for Return of Refugees and Displaced Persons to Bosnia and Herzegovina. It is a strategic and operative planning of framework allowing UNHCR to efficiently and spontaneously respond to issues raised in connection with organized return of refugees and IDPs to areas where they formerly lived. The program is set flexibly, counting on voluntary decision of concerned persons to return to the territory of their origin.

In 1996 UNHCR planned to return up to 500,000 displaced persons and 370,000 refugees.

\section{Positive Post-Dayton Developments}

After the signing of the Dayton Peace Agreement in December 1995, civil war in Bosnia-Herzegovina ended. Humanitarian aid started to reach all areas in Bosnia-Herzegovina where displaced persons found refuge. With 
Table 2: Refugues from Bowla and Herzegovina in Host Countries (Sltuation as of 1 March 1997)

\begin{tabular}{|c|c|c|c|}
\hline Current location & $\begin{array}{l}\text { Durable and } \\
\text { other solutions* }\end{array}$ & $\begin{array}{c}\text { Persons still } \\
\text { without durable } \\
\text { solutions }\end{array}$ & $\begin{array}{c}\text { Projected } \\
\text { numbers of } \\
\text { returnees 1997** }\end{array}$ \\
\hline Austria & 69,000 & 11,012 & 4,000 \\
\hline Belgium & 175 & 5,709 & 500 \\
\hline Croatia & 128,000 & 160,000 & 30,000 \\
\hline Czech Republic & 4,510 & 850 & 1,000 \\
\hline Denmark & 20,900 & 1,910 & 2,500 \\
\hline Finland & 1,350 & - & - \\
\hline France & 7,600 & 7,400 & $\mathrm{n} / \mathrm{a}$ \\
\hline FRY & $\mathrm{n} / \mathrm{a}$ & 253,377 & 37,000 \\
\hline FYROM & 2,210 & 5,000 & 5,000 \\
\hline Germany & 30,000 & 315,000 & 100,000 \\
\hline Greece & 3,750 & 250 & $\mathrm{n} / \mathrm{a}$ \\
\hline Hungary & 1,600 & 1,600 & 1,280 \\
\hline Italy & $\mathrm{n} / \mathrm{a}$ & 8,430 & 1,000 \\
\hline Liechtenstein & 159 & 237 & $\mathrm{n} / \mathrm{a}$ \\
\hline Luxembourg & 1,350 & 466 & $\mathrm{n} / \mathrm{a}$ \\
\hline Netherlands & 17,500 & 6,000 & 3,000 \\
\hline Norway & 12,000 & - & 2,000 \\
\hline Slovak Republic & 2,138 & 262 & 231 \\
\hline Slovenia & 25,000 & 8,370 & 3,100 \\
\hline Spain & $\mathrm{n} / \mathrm{a}$ & 2,000 & $\mathrm{n} / \mathrm{a}$ \\
\hline Sweden & 61,630 & 1,900 & 2,000 \\
\hline Switzerland & 7,100 & 19,567 & 8,000 \\
\hline Turkey & 2,200 & 1,800 & $\mathrm{n} / \mathrm{a}$ \\
\hline United Kingdom & 1,400 & 4,600 & $\mathrm{n} / \mathrm{a}$ \\
\hline Subtotal & 399,572 & 815,740 & 200,611 \\
\hline Australia & $24,000 * * *$ & 0 & 0 \\
\hline Canada & 38,000 & 0 & 0 \\
\hline Ireland & 748 & 19 & $\mathrm{n} / \mathrm{a}$ \\
\hline New Zealand & 143 & 0 & 0 \\
\hline USA & 38,000 & 0 & 0 \\
\hline
\end{tabular}

* Humanitarian status; other resident status; resettlement; repatriation.

** These figures are based on projections made available by countries hosting refugees from Bosnia and Herzegovina.

*** As at 31 December 1996.

Source: Humanitarian Issues Working Group, Bosnia and Herzegovina: Repatriation and Return Operation 1997, UNHCR, Geneva, April 1997, 5. 
the assistance of the Organization for Security and Cooperation in Europe (OSCE), parliamentary elections have been organized, as well as participation of refugees in them. Diplomatic relations have been established between FR Yugoslavia and Former Yugoslav Republic of Macedonia (FYROM), as well as between FRY and Republic of Croatia, while negotiations are under way between FR Yugoslavia and Bosnia-Herzegovina, and between FRY and Republic of Slovenia. According to UNHCR data, some 88,000 refugees and displaced persons returned to their homes (Table 3), which is far below the planned number.

According to the UNHCR, more than 1.2 million Bosnians sought refuge in neighbouring countries and further afield during the war years. Some 399,000 of them have already found a durable solution, have been granted a more permanent status or are in the process of acquiring new citizenships. Within this group, as noted above, 88,000 have actually repatriated to Bosnia and Herzegovina during the course of 1996 . The remaining 815,000 refugees from Bosnia and Herzegovina are still in need of durable solutions.

Also, Croatian refugees in FRY are expected to repatriate voluntarily during 1997-98. UNHCR and the federal authorities of FRY believe that the primary and best solution for refugees is voluntary repatriation. Such repatriation will take place in the framework of the Normalization Agreement between the Republic of Croatia and FRY, as well as any additional agreements which may be concluded in the framework of tripartite discussions on repatriation with UNHCR. It is expected that an 60,000 Croats who fled Eastern Slavonia to other parts of Croatia will return to Eastern Slavonia or to locally integrate in other parts of Croatia.

Over 30 percent of the population of Bosnia and Herzegovina has been displaced internally as a consequence of the war. According to UNHCR statistics, some 102,363 internally displaced

Table 3: Summary of Organized and Spontaneous Repatriation to Bosnia and Herzegovina in 1996 (Repatriation from Asylum Countries)

\begin{tabular}{lrrr}
\hline Federation & Organized & Spontaneous & Total \\
\hline Una-Sana & 12,168 & 10,717 & 22,885 \\
Posavina & 88 & 8,344 & 8,432 \\
Tuzla-Podrinje & 1,825 & 3,870 & 5,695 \\
Zenica-Doboj & 1,297 & 1,599 & 2,896 \\
Gorazde & 246 & 436 & 682 \\
Central Bosnia & 384 & 1,618 & 2,002 \\
Neretva & 761 & 0 & 761 \\
West-Herzegovina & 6 & 0 & 6 \\
Sarajevo & 3,857 & 25,143 & 29,000 \\
Tomislavgrad & 20 & 4,904 & 4,924 \\
Unknown destination & 2,831 & 0 & 2,831 \\
Subtotal & 23,483 & 64,556 & 80,114 \\
\hline Republika Srpska & 0 & 56,631 & 7,925 \\
Total & 23,483 & 7,925 & 88,039 \\
\hline
\end{tabular}

Source: Humanitarian Issues Working Group, Bosnia and Herzegovina: Repatriation and Return Operation 1997, UNHCR, Geneva, April 1997, 36.

persons, composed mainly of Muslims and some Croats, returned to their places of origin in the Federation territory and 61,854 in Republika Srpska, during 1996. In Republika Srpska, the authorities now estimate the number of internally displaced persons at 416,000 . In the Federation, the authorities and UNHCR have agreed to use a working figure of 450,000 as a reliable estimate of the present situation.

The implementation of Re-admission Agreements with Germany and Switzerland for returning rejectedasylum seekers in Germany (up to 120,000 Yugoslavs, mostly Kosmet Albanians) and Switzerland (some 11,000 rejected asylum-seekers, mostly ethnic Albanians) to FRY was not carried out as expected. The reason is attributable to the unfavourable economic and political situation in FRY, especially in the provinces of Kosovo and Metohija.
Negative Tendencies_-Obstacles to Return of Refugees and Internally Displaced Persons

Those involved in the resolution of refugee problems encountered a host of negative tendencies. Resistance of nationalist forces is still strong. This resistance is particularly obvious in matters such as citizenship (Republic of Croatia), ownership rights and general amnesty.

After operations "Lightning" and "Storm" in 1995, Croatia passed laws and by-laws in contradiction even of the state's Constitution. Thus, the government ruling on temporary appropriation and management of certain property of refugees (31 August 1995), which was later transformed into the law (Parliament decision of 20 September 1995) is a unique act of the state which takes possession of the property 
Table 4: Main Majorty Destinations in Bosula and Hercogovina for 1997*

\begin{tabular}{lrr}
\hline Federation Cantons & Returnees & Percent \\
\hline Una Sana & 27,000 & 16.90 \\
Posavina & 12,000 & 6.30 \\
Tuzla-Podrinje & 23,000 & 14.40 \\
Zenica Doboj & 16,500 & 9.40 \\
Gorazde & 2,000 & 1.20 \\
Central Bosnia & 16,000 & 8.80 \\
Neretva & 14,500 & 8.10 \\
West Herzegovina & 1,000 & 0.60 \\
Sarajevo & 43,000 & 31.20 \\
Tomislavgrad & 5,000 & 3.10 \\
Subtotal & 160,000 & 100.00 \\
\hline Republika Srpska Regions & Returnees & Percent \\
\hline Banja Luka & 17,000 & 42.50 \\
Bijeljina & 3,500 & 8.70 \\
Doboj & 6,000 & 15.00 \\
Sokolac & 1,500 & 3.70 \\
Srbinje & 2,500 & 6.30 \\
Trebinje & 1,500 & 3.80 \\
Vlasenica & 8,000 & 20.00 \\
Subtotal & 40,000 & 100.00 \\
\hline Total & 200,0000 & \\
\hline & & \\
\hline
\end{tabular}

- The indicated Cantons in Federation and Regions in Republika Srpska comprise a number of municipalities.

Source: Humanitarian Issues Working Group, Bosnia and Herzegovina: Repatriation and Return Operation 1997, UNHCR, Geneva, April 1997, 8.

in a way which is nothing but pure confiscation. Furthermore, Croatia applied selective approach to the Amnesty Act, in awarding citizenship and personal documents. Members of other nations are also subject to various other pressures with the aim of maintaining "ethnically pure territory."
Besides, conditions for repatriation are either poor or lacking altogether. During the four-year war BosniaHerzegovina was heavily destroyed. Houses have been demolished, economic facilities ruined, livestock population exterminated. Many people, both from the country and from the cities, have no place to return to.
One of the biggest problems is regaining confidence. Without absolute trust and security in the protection of human rights, ethnic and religious freedoms, refugees are unlikely to decide to return.

\section{Vital Prerequisites for Repatriation of Refugees and Internally Displaced Persons}

The breakup of SFRY and armed conflicts which inflicted two republics of the former Yugoslavia, disturbed the life of nearly ten million persons. Family relations became complicated, many marriages have been destroyed, relations between parents and children have been hampered, etc. The health situation in the region worsened. Besides forced migrations, voluntary migrations increased as well. In addition, refugees have not been treated equally in all states of the former Yugoslavia.

There are two critical problems faced by those who decided to remain in the state where they sought refuge, concretely in FRY - employment and housing. During the Yugoslav crisis, compatriots abroad showed great understanding for refugees and provided valuable aid. Emigrants have financed housing construction for their refugee relatives and friends in FRY. They have also made direct investments in the Yugoslav economy to create new jobs. With some aid from abroad, refugees started to organize business life. In the past four-year period, refugees founded over 3,500 enterprises in Serbia. ${ }^{6}$

Certain conditions must be met for the return of refugees, above all personal security and respect of human rights. Restriction of the right to move within Bosnia-Herzegovina impedes or discourages this process. Provocations have harmed the establishment of mutual confidence. The Peace Agreement envisages Bosnia-Herzegovina as a single state with extreme independence of entities. Citizens will possess documents issued according to the records of respective ministries of interior affairs. Passports will bear the name of Bosnia-Herzegovina, with 
an indication "Republika Srpska" or "Federation."

In sum, implementation of plans for repatriation of refugees and internally displaced persons largely depends on security, i.e. making sure that lives of returnees are not threatened; on the pace of repair and construction of living quarters for refugees; on the pace of mine and ground clearing in the areas where refugees will settle.

As the war which erupted with the disintegration of Yugoslavia exacerbated decades old ethnic and political tensions inherent in the countries of the region, repatriation must be voluntary and gradual. It is extremely difficult to achieve trust and peace in a poor society with people who have been indoctrinated, and it is even more difficult to build a civil society. As a policy option, "sticks" that the international community has used directly or indirectly (that is, economic sanctions) should be replaced with "carrots." The doors of international economic, trade, financial, and other organizations should be opened as part of a larger program of active and direct assistance to establish democracy in the tormented Balkan region. According to the Southeast European Cooperative Initiative (SECI), a plethora of initiatives have been conceived by the international community in attempts to abate hostilities and foster a spirit of peace and cooperation in Southeast Europe.

\section{Conclusion}

Refugees should not be the subject of political manipulation, and their choice whether to stay in exile or return to the native country must be made without undue pressure, based on realistic evaluations and adequate guarantees.

Parties which fought in the civil war for five years would have to show their earnest political will and readiness to carry out the plans for return of refugees and displaced persons. They should pass and fully observe general amnesty laws, with the exception of war crimes.
The international community should have to support all aspects of the Dayton Peace Agreement, which stipulates necessary material aid for its full implementation. The success of each separate annex to the Peace Agreement will, no doubt, affect the implementation of Annex 7, referring to return of refugees and displaced persons.

Even with full implementation of the Dayton Peace Agreement, some refugees will not want or could not return to areas which they had to leave. The international community has to facilitate possible and assist their integration in exile countries.

Since repatriation of refugees is not proceeding according to the plan, nor quite in conformity with the principles of the Dayton Peace Agreement, remedial action must be considered. Perhaps an international conference on return of refugees and economic recovery of the region may stimulate such activity.

\section{Notes}

1. The World Almanac and Book of Facts 1997 (New Jersey: Mahwah, 1997), 840.

2. For example, see Lenard Cohen, Broken Bond: Yugoslavia's Disintegration and Balkan Politics in Transition, 2nd ed., (Boulder: Westview Press, 1993, 1995); Susan Woodward, Balkan Tragedy (Washington, DC: The Brookings Institution, 1995); Lord David Owen, The Balkan Odyssey (London: VictorGollantz, 1995), Predrag Simic, "Dynamics of the Yugoslav," Crisis Security Dialogue (Oslo), 1996, Vol. 26, no. 2; Milan Sahovic (ed.), Medjunarodno pravo $i$ jugoslovenska kriza (Beograd: Institut za medjunarodnu politiku i privredu, 1995); and others.

3. Due to the rise of Croatian, Serbian and Muslim nationalisms, as well as traditional interests of superpowers and many neighbouring states, the former Yugoslavia has been a source of instability and political turmoil for six years now. The end of the Cold War has raised important questions about the future role of the United States and Russia in Yugoslavia. During the Cold War, the Balkan region has been considered a strategic pawn in the political struggle for influence between the two superpowers. With the end of the Cold War, both powers initially appeared to have lost interest in the area. Indeed, the most striking aspect of the initial phases of the Yugoslav crisis is the marginal role played by the two superpowers. Both preferred to sit back and let the Europeans manage the crisis. The results were poor. The Yugoslav crisis has highlighted the weaknesses of the current security institutions (CSCE-the Conference on Security and Cooperation in Europe and the European Union) to deal with these new nationalistic threats. (F. Stephen Larrabee, ed., The Volatile Powder Keg: Balkan Security after the Cold War. Washington, DC: American University Press, xxv).

4. Report of the EUInquest Commission; Bulletin, July-September 1995, Commissariat for Refugees of the Republic of Serbia.

5. Porodice izbeglica u Jugoslaviji [Refugee Families in Yugoslavia], UNHCR \& Institute for Social Policy, Belgrade, 1993, 21.

6. "Digest Response," Weekly for Refugees and Civil Society, no. 13, April 1996.

\section{Bibliography}

Akhavan, P., ed. 1995. Yugoslavia, the Former and Future: Reflections by Scholars from the Region. Washington, DC: The Brookings Institution; and Geneva: The United Nations Research Institute for Social Development.

Alongi, M. 1996. Ethnic Conflict and European Security: Lessons from the Past and Implications for the Future. Conference Report. Carlisle Barracks, PA: Strategic Studies Institute.

Brunner, G. 1996. Nationality Problems and Minority Conflicts in Eastern Europe: Strategies for Europe. Gutersloh: Bertelsmann Foundation Publishers.

Centre for National Security Studies. 1995. Prevention of Military Conflicts in SouthEast Europe: International Conference. Sofia: Ministry of Defense of the Republic of Bulgaria.

Esman, M. J., and Sh. Tehami, eds. 1995. International Organizations and Ethnic Conflict. Ithaca and London: Cornell University Press.

Humanitarian Issues Working Group. 1997. Bosnia and Herzegovina: Repatriation and Return Operation 1997. Geneva: UNHCR.

Institute for Social Policy. 1993. Porodice izbeglica $u$ /ugoslaviji [Refugee Families in Yugoslavia]. Belgrade: UNHCR and Institute for Social Policy.

Janjic, D. 1996. “War Challenge to European Politics on Asylum and Refugees." In Ethnicity in Postcommunism. Belgrade: Institute of Social Sciences, Forum for Ethnic Relations and International Network Europe and the Balkans. 
Jeffries,!., ed. 1996. Problems of Economic and Political Transformation in the Balkans. London and New York: Pinter.

Johnsen, W. T. 1994. Pandora's Box Reopened: Ethnic Conflict in Europe and Its Implications. Carlisle Barracks, P A: Strategic Studies Institute.

Kashuba; M. S., and M. Ju. Martynova. 1995. Novaja etnopoliticheskaja karta Balkan. Moskva: Rosijskaja Akademija nauk, Institut etnologiji i antropologiji "N. N. Mikluho-Maklaja."

Larrabee, F. S., ed. 1994. The Volatile Powder Keg: Balkan Security After the Cold War. Washington, DC: American University Press.

Magocsi, P. R. 1993. Historical Atlas of Eas Central Europe. Vol. I. Seattle and London: University of Washington.

Pavkovic, A. 1997. The Fragmentation ofYugoslavia: Nationalism in a Multinational State.

London and New York: Macmillan Press and St. Martin's Press.

Tindemans, L. et al. 1996. Unfinished Peace:

Report of the International Commission on the Balkans. Washington, DC: Carnegie Endowment for'lnternational Peace and Aspen Institute Berlin.

United Nations. 1996. Refugees And AsylumSeekers in Europe: A Statistical Overview of Citizens from Former Yugoslavia, 19911995. Geneva: UNHCR.

UNHCR. 1996. Census of Refugee and Other War-affected Persons in the Federal Republic of Yugoslavia. Geneva: UNHCR.

-1997. "Towards Solutions in the Federa Republic of Yugoslavia." Draft Country Paper. Geneva: Regional Meeting of Ministers and Commissioners for Refugees and Displaced Persons of Bosnia and Herzegovina, Croatia and the Federal Republic of Yugoslavia.

1997. Republic of Croatia: Plan of Action 19971998 Implementation of Durable Solutions to the Problems of Refugees, Displaced Persons, Waraffected Populations and Returnees Geneva: Regional Meeting of Ministers and Commissioners for Refugees and Displaced Persons of Bosnia and Herzegovina, Croatia and the Federal Republic of Yugoslavia.

Woodward, S. L. 1995. Balkan Tragedy: Chaos and Dissolution After the Cold War. Washington, DC: The Brookings Institution. LI

\section{Asylum: A Moral Dilemma}

\author{
By W. Gunther Plaut
}

Toronto: York Lanes Press, ISBN 1-55014-239-9; 192 pages, indexed; \$19.90.

Every year the refugee landscape changes, but only in that more problems are added, fewer are solved, and all become constantly more urgent. Fuelled by the explosion of the world's popwation, the quest for asylum is one of the most pressing problems of our age. Refugee-receiving nations-located frequently, butbyno me.ans exclusively, in the Western world-have to respond to masses of humanity searching for new livable homes, Human compassion for these refugees can be found everywhere, but so can xenophobia and the desire to preserve one's nation, economic well being, and cultural integrity. The dash between these impulses represents one of the great dilemmas of our time and is the subject of Plaut's study. In exploring it, he provides a far-ranging inquiry into the human condition.

The book presents political, ethnic, philosophical, religious, and sociological arguments, and deals with some of the most troublesome and heartbreaking conflicts in the news.

Contents: The Issues; Questions Without Answers; Definitions; Religion, Natural Law, and Hospitality; A Look atHistof\}'; Some Ethical Questions; Through the Lens of Sociobiology; Community and Individual; Contended Rights: To Leave, Return, Remain;

The Practice; Refugees in Africa; Four Asian Lands; Glimpses of Europe and Central America; The North American Experience; The Sanctuary Movement; A Final Look; Bibliography; Index.

Asylum-A Moral Dilemma is simultaneously published in the United States by Praeger Publishers, andin Canada by York Lanes Press.

Available from the Centre for Refugee Studies

\section{Breaking Ground: The 1956 Hungarian Immigration to Canada Edited by Robert H, Keyserlingk}

Toronto: York Lanes Press, 1993, ISBN 1-55014-232-1, 117 pages, \$6.99

This book is a collection of personal and archival-based memories on the selection, transPQrt and settlementQf about 40,000 Hungadanrefugees in Canada in one year. It is a source Qf primary record as well as scholarly reflection on one of the most significant refugee. movements to Canada a(ter WQrldWar n; the1956 Hungarian refugee. movement.

Based on papers that were presented at a 1990 conference, the authors touch on the unique political, adtninistrativeandsettlement features oHhis movement.The reSUlting work, edited by Professor Keyserlingk, is a unique mix Qf personal reminiscences and academic scholarship

Available from the Centre for Refugee Studies 